\title{
Development of Student Activity Sheet Scientific Literacy Oriented in Acid-Base Matter
}

\author{
Pipit Soleka Listyaningrum \\ Chemistry Education, College Student, \\ State University of Surabaya \\ Surabaya, Indonesia
}

\author{
Bertha Yonata \\ Chemistry Education, Post Graduate, \\ State University of Surabaya \\ Surabaya, Indonesia \\ berthayonata@unesa.ac.id
}

\begin{abstract}
The aims of the research is to describe the feasibility of student worksheet science literacy oriented in acid-base matter assessed from criteria the validity, practicality, and effectiveness. The type of research uses 4D development method that limited until development stage (Develop). The instrument are the review and validation sheet, student response sheet, and the science literacy skill test sheet. The student worksheet was tested to 15 students of state senior high school of 1 Sambit Ponorogo. The feasibility of student worksheet in terms of validity is obtained based on assessment by validator consisting of two chemistry lecturers of State University of Surabaya and one chemistry teacher of state senior high school of 1 Sambit Ponorogo. The validation by experts about content validity and construct validity obtained a percentage in a row that is $87,36 \%$ and $86,76 \%$ with the category is very valid. The feasibility of student worksheet in term of practicality is obtained based on responses of student who get a positive response of $98,33 \%$ with a very practical category. The feasibility of student worksheet in term of effectiveness is obtained based on result student science literacy skill test with a score of 459.5 to 583.3 with level 2 to level 4 above the average score of scientific literacy of Indonesian students in PISA 2015.
\end{abstract}

Keywords- Students Activity Ssheet, Scientific Literacy, Acid-Base .

\section{INTRODUCTION}

Education is one form of dynamic human culture and developmental conditions. Education that is able to support development in the future is education that is able to develop the potential of students, so that those concerned are able to face and solve the problems of life [1].

Improving the quality of education cannot be separated from various improvement efforts, one of which is the renewal of the curriculum to develop the potential of students so that human beings are smart, independent and competitive. Efforts to improve the quality of education in 2013 the government has established the 2013 Curriculum which is an improvement of the Education Unit Level Curriculum. This is reinforced by the 2013 curriculum objectives which are to prepare Indonesian people to have the ability to live as individuals and citizens who are faithful, productive, creative, innovative, and affective through strengthening integrated attitudes, skills and knowledge and able to contribute to community life, nationhood, state, and world civilization [2]. Thus to integrate the 2013 curriculum in learning, the education process is expected to be able to form human beings who are fully literate in science and technology.

The main concern of education in the 21 st century is to prepare life and work for society. In the 21 st century, the Indonesian nation faces enormous global challenges. Countries in the world are increasingly racing to win the era of global competition which is marked by the advancement of science and technology. Increased ability and understanding of science and technology is the key to the progress of a nation [3].

The aim of science education is to increase the competencies of students to be able to fulfill their needs in various situations. With these competencies, students will be able to learn further and live in a society that is currently heavily influenced by the development of science and technology. That way, students can be useful for themselves and the community. That competence is what is meant as scientific literacy [4]. Science literacy is important because it can develop several abilities, one of which is able to provide an explanation of phenomena that occur based on concepts that have been understood, and can use scientific methods in solving problems in everyday life. Broadly speaking, scientific literacy has the same meaning that is able to apply scientific concepts in solving everyday problems [5].

Scientific literacy by PISA is defined as the capacity to use scientific knowledge, to identify questions and draw conclusions based on the facts in order to understand and make decisions regarding the nature and the changes made to nature through human activity [6]. Specifically scientific literacy means being able to apply concepts or facts obtained in school with natural phenomena that occur in everyday life. PISA 2015 establishes four major dimensions of scientific literacy, namely the attitude towards science, scientific competence, scientific knowledge and the context of scientific applications. Thus students are able to use scientific knowledge and can apply it in solving everyday problems related to the material being studied [7].

Learning science as well as chemical subjects basically aims to build scientific literacy of students. This is in line with the government's expectations in PP No. 19 of 2005 National Education Standards Article 6 paragraph (1), science learning has the scope to recognize, respond, appreciate and understand science, develop habits of scientific thinking such as critical thinking and creative, independent, and have a positive attitude [8]. But in reality it 
is different, students at this time are not able to use scientific knowledge and chemical knowledge in particular to define questions, make decisions based on facts and link them in daily life.

Scientific literacy-oriented learning can be applied in the concept of chemistry, because chemistry is part of science. Many chemical concepts related to everyday life. One chemical material that is very closely related to everyday life is acid-base material. In this study the chemical material to be studied is acid-base material. Acid-base material is one of the materials in chemistry learning that is taught in class XI even semester. Learning acid-base chemistry emphasizes giving direct learning experiences to concrete objects related to acid-base material. Learning acid-base chemistry leads more to planting concepts and chemical calculations for students. Giving experience in chemistry learning is done through activities at the Laboratory.

Based on the results of a pre-research questionnaire at State senior high school of 1 Sambit Ponorogo on September $30,2017,54.55 \%$ of the chemistry lessons were difficult, and as many as $54.55 \%$ of students did not understand the real usefulness of the material learned at school in their daily lives. day. As many as $100 \%$ of students use student worksheet in learning chemistry, but in reality student worksheet used by students lacks training in scientific literacy skills of students. This is supported by the results of the pre-study problem analysis of students which showed that as many as $76.19 \%$ of students had the competence to explain unfavorable phenomena, $69 \%$ of students were not good at evaluating and designing scientific investigations, and as many as $38 \%$ of students were less both in interpreting scientific data and evidence. Based on questionnaires and scientific literacy questions for students at State senior high school of 1 Sambit Ponorogo, it can be concluded that there is no student whorksheet to train students' scientific literacy so that researchers choose to develop student worksheet scientific literacy-oriented learning can be applied in the concept of chemistry, because chemistry is part of science. One of them is in the acid base material. Addressing these problems was conducted by research "Development of student worksheet Scientific Literacy in Class XI High School Acid-Base Material. This study aims to describe the feasibility of the developed student worksheet scientific literacy oriented.

\section{METHODS}

This research is a LKPD development study that uses model development design 4-D proposed by Thiagarajan, Semmel \& Semmel (1974). The stages carried out in this study are only limited to the third stage, namely development (Develop).

This development design consists of four main stages, namely the stage of defining, designing, developing and distributing. The defining study phase consists of front end analysis, student analysis, task analysis, concept analysis, and formulation of learning objectives. In the design study consists of the preparation of tests, media selection, and format selection. During the development phase includes device validation and limited testing.

The objective of this research is the scientific literacy oriented Student Activity Sheet on acid-base material in class XI senior high school. The subjects in this study were 15 students of class XI science 1 at State senior high school of 1 Sambit Ponorogo on even semester who had diverse academic abilities and had received acid-base material.

The instruments used in this study include: study sheets, validation sheets, student questionnaire response sheets, student activity observation sheets, and students' scientific literacy ability test sheets.

Student worksheet product design that has been completed as draft I, will then be reviewed by a chemistry lecturer at Surabaya State University and one chemistry teacher at state senior high school of 1 Sambit Ponorogo which is used to obtain comments and suggestions from reviewers for improvements to student worksheet developed. Then the revision was carried out in accordance with the comments and suggestions from experts who then produced draft II. The data obtained, then will be analyzed qualitatively qualitative.

The second draft produced was then validated by two chemistry lecturers from State University of Surabaya and one chemistry teacher from State senior high school of 1 Sambit Ponorogo. Data from the validation results were analyzed quantitatively by percentage. The percentage is obtained by comparing the scores of the data collected from all validators with the criteria score. Assessment using the calculation of the Likert scale as presented in Table 1 is as follows:

TABLE I. LIKERT SCALE

\begin{tabular}{|c|c|}
\hline Value & Criteria \\
\hline 1 & Very Poor \\
\hline 2 & Poor \\
\hline 3 & Moderate \\
\hline 4 & Good \\
\hline 5 & Very Good \\
\hline
\end{tabular}

Calculation data that has been calculated percentages then interpreted into score interpretation as in Table 2 as follows: TABLE 2 INTERPRETATION S CORE VALIDATION RESULTS

\begin{tabular}{|c|c|}
\hline Percentage (\%) & Criteria \\
\hline $0-20$ & Invalid \\
\hline $21-40$ & Less valid \\
\hline $41-60$ & Valid enough \\
\hline $61-80$ & Valid \\
\hline $81-100$ & Very valid \\
\hline
\end{tabular}

Student worksheet developed as valid if the percentage results of $\geqslant 61 \%$ with a valid to very valid category [6]. which has been validated is then limited to 15 students of class XI Science 1 in State Senior High School of 1 Sambit Ponorogo.

After limited trials obtained results in the form of questionnaires response students who are supported by the activities of students to find out the practicality of the developed LKPD. Data from the questionnaire responses of students were analyzed quantitatively descriptively based on the Guttman Scale calculation as shown in Table 3 below.

TABLE 3 GUTTMAN SCALE CRITERIA

\begin{tabular}{|c|c|c|}
\hline Statement & Answer & Score \\
\hline \multirow{2}{*}{ Positive } & Yes & 1 \\
& No & 0 \\
\hline
\end{tabular}




\begin{tabular}{|l|l|l|}
\hline Negative & Yes & 0 \\
No & 1 \\
\hline
\end{tabular}

As a percentage then interpreted in accordance with Table 4 as follows:

TABLE 4 INTERPRETATION SCORE QUESTIONNAIRE RESPONSES OF STUDENTS

\begin{tabular}{|c|c|}
\hline Percentage (\%) & Criteria \\
\hline $0-20$ & Not Practical \\
\hline $21-40$ & Less Practical \\
\hline $41-60$ & Practical Enough \\
\hline $61-80$ & Practical \\
\hline $81-100$ & Very Practical \\
\hline
\end{tabular}

The developed LKPD is said to be valid if it meets the percentage results of $\geqslant 61 \%$ with a valid to very valid category [6].

The response of students is supported by observational data of student activities during the learning process. The data is filled by 3 observers. The activities of students are said to be carried out well and support the effectiveness of the application of scientific literacy oriented LKPD that is developed if the percentage of relevant student activity is greater than the activity of students who are not relevant.

In addition, the data obtained in the form of scientific literacy ability test results of students. Assessment of students' scientific literacy abilities is done after students use the developed LKPD. The results of the assessment were obtained through the test questions sheet that had been prepared previously and calculated by the formula:

$$
\text { Witai bterast sans }=\frac{\sum(B t \times b i)}{s t} \times 707
$$

Description:

$\mathrm{Bi}=\quad$ Number of questions answered correctly students

bi $=$ Weight of each item with different levels ( adopted from PISA)

St $=$ theoretical score (score if correct all items)

(Poerwanti adaptation, 2008)

Scientific literacy scores were then analyzed in the range of scientific literacy scores according to Table 4 as follows:

TABLE 4 SCORES OF SCIENCE LITERACY

\begin{tabular}{|c|c|}
\hline Level & Score \\
\hline 1 & $335-408$ \\
\hline 2 & $409-483$ \\
\hline 3 & $484-558$ \\
\hline 4 & $559-632$ \\
\hline 5 & $663-706$ \\
\hline 6 & 707 \\
\hline
\end{tabular}

Based on these criteria, scientific literacy skills can be said to be successfully trained if scientific literacy skills can reach above the average scientific literacy score of students Indonesia in PISA 2015 is $\geq 403$ (above level 1 PISA).

\section{RESULT AND DISCUSSION}

This study aims to describe the feasibility of scientific literacy-oriented student worksheet in class XI SMA acid base material reviewed based on validity, practicality and effectiveness.

\section{A. Validity of Student Worksheet}

validity The validity of the developed worksheet was obtained through a validation process by a validator consisting of two Surabaya State University chemistry lecturers and one chemistry teacher at SMA 1 Sambit Ponorogo. Before the validation stage, draft 1 was student activity worksheet first reviewed by a Surabaya State University chemistry lecturer and one chemistry teacher from SMA 1 Sambit Ponorogo to get comments and suggestions for the improvement of the developed student worksheet.

Based on the results of the review obtained several comments and suggestions from the reviewers, including: relating to thecover student worksheet to be more representative so that it can facilitate students to know the contents of the material and look for it, add KD and GPA on each cover student worksheet and clarity of the image source. These suggestions and inputs are then used to improve student worksheet so as to produce a draft II student worksheet which will then be validated.

In the validation process, student worksheet was assessed based on the criteria of content validity and construct validity [15].

TABLE 5 VALIDATION RESULTS BASED ON CRITERIA FOR VALIDITY OF CONTENT

\begin{tabular}{|c|c|c|}
\hline Aspects Assessed & $\begin{array}{c}\text { Percentage } \\
(\%)\end{array}$ & Criteria \\
\hline $\begin{array}{l}\text { Student worksheet } \\
\text { Suitability with Material }\end{array}$ & 88.40 & $\begin{array}{c}\text { Very } \\
\text { Valid }\end{array}$ \\
\hline $\begin{array}{l}\text { Material suitability with } \\
\text { scientific literacy ability }\end{array}$ & 86.76 & $\begin{array}{c}\text { Very } \\
\text { Valid }\end{array}$ \\
\hline $\begin{array}{l}\text { Compatibility of student } \\
\text { worksheet with domain } \\
\text { scientific literacy }\end{array}$ & 86.76 & $\begin{array}{c}\text { Very } \\
\text { Valid }\end{array}$ \\
\hline \multicolumn{1}{|c|}{ Average } & 87.36 & $\begin{array}{c}\text { Very } \\
\text { Valid }\end{array}$ \\
\hline
\end{tabular}

TABLE 6 VALIDATION RESULTS BASED ON CRITERIA FOR THE CONSTRUCTIONVALIDITY

\begin{tabular}{|l|c|c|}
\hline \multicolumn{1}{|c|}{ Aspect } & $\begin{array}{c}\text { Percentage } \\
(\mathbf{\%})\end{array}$ & Criteria \\
\hline Linguistic & 86.76 & Very Valid \\
\hline Presentation & 86.76 & Very Valid \\
\hline Integrity & 86.76 & Very Valid \\
\hline Average & 86.76 & Very Valid \\
\hline
\end{tabular}

Validation results show that student worksheet is oriented towards scientific literacy in acid-base material developed in terms of material suitability criteria of $88.40 \%$, material suitability criteria with scientific literacy ability of $86.76 \%$, student worksheet suitability criteria with science literacy domain of $86.76 \%$, criteria linguistic is $86.76 \%$, presentation criteria is $86.76 \%$, and graphic criteria is $86.76 \%$. Based on the results of the validation obtained, it 
can be said that the scientific literacy oriented student worksheet developed is feasible to use.

\section{B. Practicality of Student Worksheet}

practicality of the student worksheet developed was reviewed based on the responses of students and supported by the activities of students during the learning using the developed student worksheet. The response questionnaire contains a number of positive and negative questions with the choice of "Yes" or "No" answers distributed after the implementation of learning using student worksheet which was developed for a number of 15 trial students. The developed student worksheet is said to be practical if the data from the questionnaire responses of students show $\geq 61 \%$ positive response [6].

Based on the results of the questionnaire responses of students, the developed student worksheet received an average response of $98.33 \%$ or categorized as very practical. Practically described as student worksheet products that are developed are easy to use and understand [15]. Response questionnaire data is supported by observations of students' activities during the learning process using the developed student worksheet.

Based on data from observations of student activities it can be seen that during the limited trial activities using student worksheet science literacy-oriented on acidbase material, students have higher relevant activities with an average percentage at the first meeting, the second meeting, the third meeting and the fourth meeting. amounting to $96.75 \%$.

This shows that students during the learning process are very enthusiastic and interested when using the developed student worksheet, so it can be concluded that the questionnaire responses are filled in by students in accordance with their actual opinions and circumstances and relevant to the results of the observed activity.

\section{The effectiveness of student worksheet}

The effectiveness of the Student Literacy Activity Sheet oriented on acid-base material is measured based on the results of the scientific literacy ability of students. The instrument used to obtain data on students' scientific literacy abilities is in the form of question scientific literacy ability test.

Table 7 Science Literacy Test Results of Students

\begin{tabular}{|c|c|c|}
\hline Students & Score & Level \\
\hline BAF & 583.3 & 4 \\
\hline EY & 583.3 & 4 \\
\hline PDC & 521.4 & 3 \\
\hline SNH & 459.5 & 2 \\
\hline SJAS & 521.4 & 3 \\
\hline DPW & 459.5 & 2 \\
\hline ELKJ & 521.4 & 3 \\
\hline MS & 583,3 & 4 \\
\hline NAS & 459.5 & 2 \\
\hline YNR & 583.3 & 4 \\
\hline AFS & 521.4 & 3 \\
\hline DAS & 583.3 & 4 \\
\hline DR & 521.4 & 3 \\
\hline HA & 521.4 & 3 \\
\hline MA & 521.4 & 3 \\
\hline
\end{tabular}

Results of the scientific literacy ability test of students in general after being trained using student worksheet the scores obtained were 459.5 to 583.3 with level 2 to level 4 above the average score of scientific literacy of Indonesian students in the 2015 PISA with a score of 403 (at level 1). Based on the results of the scientific literacy ability test, students can conclude that student worksheet oriented in scientific literacy on acid-base material developed meets the criteria of effectiveness or is suitable for use as teaching material.

\section{Conclussions}

Based on the results and discussion of the study, it can be concluded that the Student Literacy Activity Sheet (LKPD) oriented to acid-base material that has been developed has been feasible to be used as teaching material because it has reached and fulfilled all the eligibility criteria, namely as follows :

1. Based on the aspect of validity, the developed LKPD was declared to be very valid and was reviewed based on the results of an evaluation from a validator consisting of two Surabaya State University chemistry lecturers and one chemistry teacher. Validity values in terms of content validity and construct validity with successive percentages of $87.36 \%$ and $86.76 \%$ in very valid categories.

2. Based on the practicality aspect, the developed LKPD was assessed as practical in terms of the responses of students by getting a positive response of $98.33 \%$ with a very practical category supported by observations of students' activities during learning by obtaining relevant activities by $96.75 \%$ with very good interpretation. Based on the effectiveness aspect, the developed LKPD was assessed as practical in terms of the scientific literacy ability test of students in levels 3 - 4 PISA.

1. Based on the effectiveness aspect, the LKPD developed was considered effective in terms of the results of the scientific literacy ability test of students who received scores of 459.5 to 583.3 with levels 2 to level 4 which were above the average score of scientific literacy of Indonesian students in PISA 2015 with a score of 403 (at level 1).

\section{ACKNOWLEDGMENT}

We thank Mr Muchlis and Mrs Kusumawati Dwiningsih from Department of Chemistry, State University of Surabaya, for help in guided and validation of the teaching materials.

\section{REFERENCES}

[1] Trianto,. Integrated Learning Model. Jakarta: Bumi Aksara, 2010

[2] Ministry of Education and Culture.. Permendikbud No. 81A about Implementation of Curriculum. Jakarta: Minister of Education and Culture, 2013

[3] Trilling, B. Dan Hood, P. Learning, Technology, and Education Reform in the Knowledge Age. USA: Educational Technology. 1999

[4] Toharudin, U., Hendrawati, S., and Rustaman, A. Building Students' Science Literacy. Bandung: Humanities, 2011

[5] Lukman, Y., H. Suwono., \& E. Suarsini. The Effect of Blended Learning-Based Guided Learning on Science Literacy and Student 
Learning Outcomes of Class XI of Malang 5 State Senior High School. Essay. Malang: Department of Biology, Faculty of Mathematics and Natural Sciences UM, 2015

[6] OECD. Assessment Framework: Key competencies in reading, mathematics and science. Not published. 2015

[7] OECD. PISA 2015 Draft Science Framework. Not published. 2015

[8] Ministry of National Education. Government Regulation Number 19 of 2005 concerning National Education Standards, Jakarta: Ministry of National Education. 2005

[9] Aqib, Zainal and Ali Murtadl. Collection of Creative and Innovative Learning Methods. Bandung: PT Tutorial Means Nurani Sejahtera. 2016

[10] Ministry of Education. Guide to the Development of Teaching Materials. Jakarta: Ministry of National Education Directorate General of National Education Management Primary Secondary Education Directorate of Senior High School Development, 2008
[11] Emanuel, Richard C and Siu Challons-Lipton. Helping Students Transition to Critical and Creative Thinking at the Intersection of Communication and Art. International Journal of Humanities and Social Science, 2012, Vol. 2 No. 11.

[12] Joyce, Bruce. Model of Teaching: Teaching Models. (Achmad Fawaid and Ateilla Mirza Translation). Eighth edition. Yogyakarta: Student Library. 2011

[13] Borg, WR \& Gall, MD Gall. Educational Research: An Introduction, Fifth Edition. New York: Longman. 1989

[14] Riduwan. Research Variables Measurement Scale. Bandung: Alfabeta. 2015

[15] Agustini, Rudiana, et al . Assessment. Surabaya: Chemistry Department FMIPA UNESA 2014

[16] Plomp, Tjeer and Nieveen Nieke. Education Design Research: An Introduction. SLO. Netherlands Institute for Curriculum Development. 2013 